\title{
Reproductive activity of birds in a mangrove swamp in Northwest Costa Rica
}

\author{
Gilbert Barrantes
}

Museo de Zoología, Escuela de Biología, Universidad de Costa Rica 2060 San José, Costa Rica. Fax (506)2074216, gbarrantes@cariari.ucr.ac.cr

Received 24-IV-1998. Corrected 1-IX-1998. Accepted 10-IV-1998.

\begin{abstract}
Resumen: La riqueza avifaunística en los manglares es relativamente alta contrastando con su pobre diversidad florística. Durante 18 meses (julio 1986 a diciembre 1987) visité por ocho días cada dos semanas un área de manglar de 200 hectáreas en Chomes, noroeste de Costa Rica. En estas visitas cuantifiqué la actividad reproductiva de las especies residentes de este manglar. El 55\% de las 69 aves terrestres residentes se reproducen en el manglar. Probablemente el número de especies así como el número de individuos que se reproducen en este ecosistema se ha incrementado con la destrucción de los bosques originales que cubrían las tierras circundantes. La destrucción de los bosques aledaños así como la del mismo manglar, incrementa el riesgo de extinción local de aquellas especies que utilizan este ecosistema como su hábitat primario, incluyendo a Amazilia boucardi, una especie endémica a los manglares de Costa Rica y cuyo límite norte de distribución es precisamente Chomes.
\end{abstract}

Key words: Mangrove avifauna, reproduction, habitat fragmentation.

Mangroves, in spite of their low floristic diversity (Pool et al. 1977, Jimenez \& Soto 1985), posses a relatively rich avifauna (Lefebvre et al. 1994). Several factors combine to favor such bird diversity in mangroves. For example, the distribution of this forest along the cost and the daily water flow, determined by the dynamics of the tide cycle, confers to mangroves particular characteristics that allow, both, aquatic and terrestrial birds to exploit this ecosystem.

In Costa Rica, mangroves in the Caribbean cost are restricted to small spots located at the river mouths. On the contrary, mangrove forest covered a narrow stripe almost along the entire Pacific cost (Gómez 1986). Nonetheless, the development of agriculture and touristic complexes have reverted such a continuous habitat into a series of mangrove islands. The effects of habitat destruction and fragmentation are well known (e.g., Carlson \& Aulen 1992). They reduce genetic variability, increase predation, and the negative effects of natural catastrophes. In general, these factors augment the risk of local extinction and lessen the biodiversity.

The destruction of mangroves have been remarkably extensive in the Northwestern region of Costa Rica. This region has historically been subjected to an indiscriminate deforestation that has resulted in the elimination of practically all lowland forested areas (Groom \& Schumaker 1993). As a consequence of the impressive destruction of the natural habitats, the isolated remnants of forest acquire great importance as reservoirs of the original avifauna. Thus, mangrove patches have become increasingly important as they are frequently the only forested areas immersed 
in an agricultural matrix. Consequently, mangrove islands have become the last refuge for many bird species that originally inhabited dry forest as well as for the specific mangrove avifauna. This study evaluates the reproductive activity of bird species that inhabit a mangrove area in Northwestern Costa Rica.

I gathered information on reproduction of bird species in a mangrove patch of approximately 200 hectares in Chomes, Puntarenas $\left(10^{\circ}, 02^{\prime} \mathrm{N}\right.$ and $\left.84^{\circ}, 54^{\prime} \mathrm{W}\right)$ by visiting the patch for a period of eight days every two weeks, from July 1986 through December 1987. During my visits to the mangrove, I walked along trails established in the edge and in the interior of the study site, seeking reproductively active birds. A bird was considered reproductively active if it was carrying nest material, building nest, incubating, or feeding nestlings or fledgelings. I also recorded whether the bird was at the edge or in the interior of the mangrove.

Climatically, the study site is characterized by a drastic dry season that extends from December through April. During the rainy season the monthly rainfall varies from 50 to $600 \mathrm{~mm}$ (Epifanio et al. 1983). The vegetation of this mangrove consists mainly of Rhizophora mangle, $R$. harrisonii, Avicenia germinans, A. bicolor, and Laguncularia racemosa, trees which form the core vegetation of the mangrove (Jiménez \& Soto 1985). Other plant species such as Clerodendrum pittieri, Conocarpus erecta, Prosopis juliflora, Pithecellobium dulce, Capparis odoratissima, and $C$. flexuosa dominate along the mangrove edge and on higher areas in the interior.

I recorded 111 bird species in the study area. From these species, 79 were resident (Zenaida asiatica, Chordeiles acutipennis, and Myiodinastes maculatus which have resident and migratory populations are considered here as resident), the rest were migrants. Sixty seven out of the 79 resident species were terrestrial whereas the rest
(12) have aquatic habits. Thirty seven of these 67 terrestrial species breed in the mangrove (considering the criteria used to define a reproductive individual; Table 1). Eighteen species reproduce at the mangrove edge, eight in the interior, and eleven in both parts of the mangrove; no significant difference was detected among the three groups $\left(X^{2}=4.27\right.$, $\mathrm{df}=2, \mathrm{p}>0.05)$. The number of breeding species recorded monthly is shown in Fig. 1. Reproduction of birds in the mangrove occurs year round, although this activity concentrates from March through July, especially from April through June (Fig. 1; K$\mathrm{S}=0.58, \mathrm{n}=12, \mathrm{p}=0.03$ ).

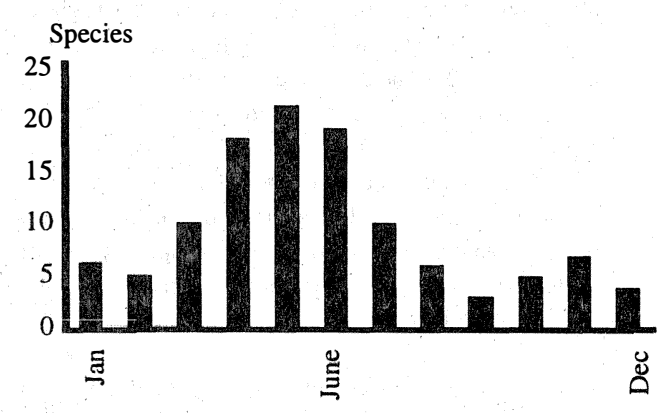

Fig. 1. Number of breeding species observed monthly in a patch of mangrove.

Reproductive activity of birds in fragments of mangroves enhance the importance of this ecosystem as a refuge for species which original habitats have been wiped out due to human activities. The shift in land use in the Northwest of Costa Rica has forced numerous bird species (e.g., Crotophaga sulcirostris, Morococcyxs erythropygius, Thamonphilus doliatus), which formerly reproduced on a much more extensive forest, to concentrate their reproductive activities on mangrove patches, in many cases the only forest available. Consequences of increasing reproductive activity on those birds that dwell exclusively (or primarily) on mangroves (e.g., Amazilia boucardi, Myiarchus panamensis, Dendroica erithachorides) are unknown. Yet, a 


\section{TABLE 1}

Bird species reproducing at the edge and in the interior of a mangrove patch in Chomes, Costa Rica. Period refers to particular dates in which birds reproductively active were observed and the question mark in that column indicates that either the beginning or the end of the reproductive period is unknown.

\begin{tabular}{|c|c|c|c|c|}
\hline Species & $\begin{array}{c}\text { Mangrove } \\
\text { interior }\end{array}$ & $\begin{array}{c}\text { Mangrove } \\
\text { edge }\end{array}$ & $\begin{array}{c}\text { Number of } \\
\text { nests }\end{array}$ & Reproductive period \\
\hline Butorides virescens & $\mathbf{x}$ & $\mathbf{x}$ & 1 & Apr 15 - May 15 \\
\hline Coragyps atratus & & $x$ & 1 & Nov $15-\operatorname{Jan} 15$ \\
\hline Buteogallus anthracinus & & $\mathrm{x}$ & 2 & Mar 25-Jun 3 \\
\hline Charadrius wilsonia & & $\mathrm{x}$ & 1 & Apr $15-?$ \\
\hline Zenaida asiatica & & $x$ & 1 & Apr 20 -? \\
\hline Columbina passerina & $\mathrm{x}$ & $x$ & 8 & $\begin{array}{l}\text { Jan } 22-\text { Aug } 20 \\
\text { Oct } 1-\text { Nov } 28\end{array}$ \\
\hline Columbina talpacoti & $x$ & $\mathrm{x}$ & 4 & Apr $20-$ jun $15+$ Nov \\
\hline Columbina inca & $\mathrm{x}$ & $\mathbf{x}$ & 6 & $\operatorname{Mar} 10-\operatorname{Dec} 9$ \\
\hline Claravis pretiosa & $\mathrm{x}$ & & 1 & Jul $11-?$ \\
\hline Aratinga canicularis & & $x$ & 1 & $?-$ Feb 23 \\
\hline Crotophaga sulcirostris & & $x$ & 1 & Aug 12-? \\
\hline Morococcyxs erythropygius & 8 & $\mathrm{x}$ & 1 & ?-Oct 16 \\
\hline Chordeiles acutipennis & & $\mathrm{x}$ & 3 & Apr $20-$ Jul 15 \\
\hline Nyctidromus albicollis & & $\mathbf{x}$ & 1 & ? - May 31 \\
\hline Anthracothorax prevostii & $\mathrm{x}$ & $\mathrm{x}$ & 3 & Dec 1 - Mar $15 /$ Nov 22 \\
\hline Chlorostilbon canivetii & $\mathrm{x}$ & & 1 & Jun 1 -? \\
\hline Amazilia boucardi & $\mathrm{x}$ & & 2 & Sep $22-$ Oct 3 \\
\hline Amazilia rutila & & $\mathrm{x}$ & 1 & Jun 1 - ? \\
\hline Eumomota superciliosa & & $\mathbf{x}$ & 2 & $\operatorname{Mar} 31$ - Apr 15 \\
\hline Melanerpes hoffmannii & $\mathrm{x}$ & $\mathrm{x}$ & 1 & Jan $23-?$ \\
\hline Lepidocolaptes souleyetii & $\mathrm{x}$ & & 1 & May $7-?$ \\
\hline Thamnophilus doliatus & & $\mathrm{x}$ & 2 & May 28 - Aug 11 \\
\hline Pachyramphus cinnamomeus & $\mathbf{x}$ & & 1 & May 31 - Jul 25 \\
\hline Pachyramphus aglaiae & & $\mathrm{x}$ & 3 & Apr $29-$ Jun 15 \\
\hline Tyrannus melancholicus & & $\mathrm{x}$ & 3 & Mar 23-Jul 18 \\
\hline Myiodynastes maculatus & $\mathrm{x}$ & & 1 & Apr $12-?$ \\
\hline Myiozetetes similis & & $\mathrm{x}$ & 2 & Mar $18-$ Jun 2 \\
\hline Pitangus sulphuratus & & $x$ & 2 & Jan 20 - Jun 2 \\
\hline Myiarchus panamensis & $x$ & & 1 & ? - May 30 \\
\hline Myiarchus tyrannulus & $\mathbf{x}$ & $\mathrm{x}$ & 2 & Apr 1 - May 27 \\
\hline Todirostrum cinereum & $\mathrm{x}$ & & 2 & May 27 - Aug 26 \\
\hline Sublegatus modestus & $\mathrm{x}$ & $\mathrm{x}$ & 2 & May 15 - Jun 28 \\
\hline Campylorhynchus rufinucha & $x$ & $\mathbf{x}$ & 3 & Dec 1 - Jun $15 /$ Nov 22 \\
\hline Polioptila albiloris & & $\mathrm{x}$ & 2 & Jun $13-$ Jul 25 \\
\hline Dendroica erithachorides & $\mathrm{x}$ & $\mathbf{x}$ & 7 & Apr $7-\operatorname{Sep} 5$ \\
\hline Quiscalus mexicanus & $\mathrm{x}$ & $\mathrm{x}$ & 6 & Mar $18-J u n 15$ \\
\hline Euphonia affinis & & $\mathrm{x}$ & 2 & Oct $2-$ Nov 17 \\
\hline
\end{tabular}


tangible and eminent threat for the mangrove avifauna is the drastic and increasing destruction of this ecosystem. Thus, large extensions of mangrove forest have been transformed to isolated fragments and consequently the movement of birds among such patches is greatly reduced. If the destruction of mangroves continues at the same rate, it will likely cause the local extinction of the mangrove dependent birds, such as Amazilia boucardi, a hummingbird endemic to Costa Rican mangroves and whose northern most extreme of its distribution is precisely Chomes.

\section{REFERENCES}

Carlson, A. B. \& G, Aulen. 1992. Territorial dynamics of an isolated White-Backed Woodpecker (Dendrocopos leucotos) population. Conserv. Biol. 6: 450-458.

Epifanio, C. E., D. Maurer \& A. I. Dittel. 1983. Seasonal changes in nutrients and dissolved oxigen in the Gulf of Nicoya, a tropical estuary on the Pacific costal of Central América. Hydrobia 101: 231-238.

Gómez, L. D. 1986. Vegetación de Costa Rica. Apuntes para una biogeografia costarricense. Editorial Universidad Estatal a Distancia, San José, Costa Rica.

Groom, M. J. \& N. Schumaker. 1993. Evaluating landscape change. Pp. 24-44. In P. M. Kareiva, J. G. Kingsolver \& R. B. Huey (eds.). Biotic interactions and global change. Sinauer, Sunderland, Massachusetts.

Jiménez, R. \& R. Soto. 1985. Patrones regionales en las estructura y composición de los manglares de la Costa Pacífica de Costa Rica. Rev. Biol. Trop. 33: 25-38.

Lefebvre, G., B. Poulin \& R. McNeil. 1994. Temporal dynamics of mangrove bird communities in Venezuela with special reference to migrant warblers. Auk 111: 405-415.

Pool, D. L., S. Snedaker \& A. E. Lugo. 1977. Structure of mangrove forests in Florida, Puerto Rico, Mexico, and Costa Rica. Biotropica 9: 195-212. 